\title{
Soil nitrogen transformation responses to seasonal precipitation changes are regulated by changes in functional microbial abundance in a subtropical forest
}

\author{
Jie Chen ${ }^{1,2,3, *}$, Guoliang Xiao ${ }^{1,2, *}$, Yakov Kuzyakov ${ }^{3,4}$, G. Darrel Jenerette ${ }^{5}$, Ying Ma ${ }^{1,2}$, Wei Liu ${ }^{1}$, Zhengfeng Wang ${ }^{1}$, \\ and Weijun Shen ${ }^{1}$ \\ ${ }^{1}$ Center for Ecological and Environmental Sciences, South China Botanical Garden, Chinese Academy of Sciences, \\ 723 Xinke Rd. Tianhe District, Guangzhou 510650, PR China \\ ${ }^{2}$ University of Chinese Academy of Sciences, 19A Yuquan Road, Shijingshan District, Beijing 100049, PR China \\ ${ }^{3}$ Department of Soil Science of Temperate Ecosystems, University of Göttingen, Büsgenweg 2, 37077 Göttingen, Germany \\ ${ }^{4}$ Department of Agricultural Soil Science, University of Göttingen, Büsgenweg 2, 37077 Göttingen, Germany \\ ${ }^{5}$ Department of Botany and Plant Sciences, Center for Conservation Biology, University of California Riverside, Riverside, \\ CA92521, USA \\ *These authors contributed equally to this work.
}

Correspondence to: Weijun Shen (shenweij@scbg.ac.cn)

Received: 8 January 2017 - Discussion started: 31 January 2017

Revised: 12 April 2017 - Accepted: 13 April 2017 - Published: 17 May 2017

\begin{abstract}
The frequency of dry-season droughts and wetseason storms has been predicted to increase in subtropical areas in the coming decades. Since subtropical forest soils are significant sources of $\mathrm{N}_{2} \mathrm{O}$ and $\mathrm{NO}_{3}^{-}$, it is important to understand the features and determinants of $\mathrm{N}$ transformation responses to the predicted precipitation changes. A precipitation manipulation field experiment was conducted in a subtropical forest to reduce dry-season precipitation and increase wet-season precipitation, with annual precipitation unchanged. Net $\mathrm{N}$ mineralization, net nitrification, $\mathrm{N}_{2} \mathrm{O}$ emission, nitrifying (bacterial and archaeal $a m o A$ ) and denitrifying (nirK, nirS and nosZ) gene abundance, microbial biomass carbon (MBC), extractable organic carbon (EOC), $\mathrm{NO}_{3}^{-}, \mathrm{NH}_{4}^{+}$and soil water content (SWC) were monitored to characterize and explain soil $\mathrm{N}$ transformation responses. Dry-season precipitation reduction decreased net nitrification and $\mathrm{N}$ mineralization rates by $13-20 \%$, while wetseason precipitation addition increased both rates by $50 \%$. More than $20 \%$ of the total variation of net nitrification and $\mathrm{N}$ mineralization could be explained by microbial abundance and SWC. Notably, archaeal amoA abundance showed the strongest correlation with net $\mathrm{N}$ transformation rates $(r \geq 0.35)$, suggesting the critical role of archaeal amoA
\end{abstract}

abundance in determining $\mathrm{N}$ transformations. Increased net nitrification in the wet season, together with large precipitation events, caused substantial $\mathrm{NO}_{3}^{-}$losses via leaching. However, $\mathrm{N}_{2} \mathrm{O}$ emission decreased moderately in both dry and wet seasons due to changes in nos $Z$ gene abundance, MBC, net nitrification and SWC (decreased by 10-21\%). We conclude that reducing dry-season precipitation and increasing wet-season precipitation affect soil $\mathrm{N}$ transformations through altering functional microbial abundance and MBC, which are further affected by changes in EOC and $\mathrm{NH}_{4}^{+}$availabilities.

\section{Introduction}

Precipitation changes caused by global climate change are predicted to be increasingly severe over the coming century (IPCC, 2007; Seager et al., 2007). Future projected precipitation patterns vary spatially and temporally, and the complexity and unpredictability of precipitation changes have exceeded other global changes such as elevated $\mathrm{CO}_{2}$ and temperature (Beier et al., 2012). In addition to the frequency and intensity of precipitation events, seasonal precipitation 
changes are of increasing severity in some regions of the world (Easterling et al., 2000). For example, an analysis of 60 years of precipitation data showed remarkable seasonal precipitation redistribution in subtropical China, with more frequent droughts in the dry season and extreme rainfall events in the wet season (Zhou et al., 2011). In contrast to changes in total annual precipitation, redistribution of seasonal precipitation may be more important in controlling ecosystem function in subtropical forests, due to strong contrasts between dry and wet seasons (Wang et al., 2009). Recent meta-analyses on precipitation manipulation experiments pointed out the lack of data in the warm and humid monsoon zones (Wu et al., 2011; Liu et al., 2016), and that more than $60 \%$ of all manipulative field experiments only focused on changes in annual precipitation amounts (Beier et al., 2012). The consequences of seasonal precipitation redistribution at ecosystem levels are still under investigation. Field experiments simulating seasonal precipitation changes in subtropical regions are urgently needed for better understanding of the ecosystem responses.

Changes in precipitation can strongly affect soil nitrogen (N) cycling and balance, thus exerting a feedback on climate (Davidson et al., 2008; Wieder et al., 2011). For instance, annual $\mathrm{N}_{2} \mathrm{O}$ emission was decreased by a rainfall exclusion experiment in the moist tropical forest, but recovered within the first year after rainfall exclusion was stopped (Davidson et al., 2008). In grasslands, the net $\mathrm{N}$ mineralization rate declined sharply in response to increased rainfall, but increased during drought (Jamieson et al., 1998). Contrasting responses of $\mathrm{N}$ transformation have also been obtained in temperate forests (Emmett et al., 2004; Chen et al., 2011; Fuchslueger et al., 2014). However, limited information exists about the responses of the $\mathrm{N}$ cycle to seasonal precipitation changes in subtropical forests, which serve as important sources of $\mathrm{N}_{2} \mathrm{O}$ emission and inorganic $\mathrm{N}$ leaching (Fang et al., 2009; Isobe et al., 2012). Seasonal precipitation changes may affect $\mathrm{N}$ transformations by disturbing the seasonal dynamics of microbial activities, soil moisture, temperature, plant nutrient uptake, and carbon (C) and $\mathrm{N}$ availabilities (Reichmann et al., 2013). Although the direct effects of soil physicochemical properties and microbial communities on $\mathrm{N}$ transformations are well documented, the dominant factors in determining $\mathrm{N}$ transformations under precipitation changes are still debatable (Petersen et al., 2012; Auyeung et al., 2015).

Ammonium oxidation, the central and rate-limiting step in $\mathrm{N}$ cycling, is driven by ammonia-oxidizing archaea $(A O A)$ and bacteria $(A O B)$, which are marked by the $a m o A$ functional gene (van der Heijden et al., 2008). The release and consumption of $\mathrm{N}_{2} \mathrm{O}$ by denitrification are mainly driven by nitrite-reducing bacteria carrying the nirK and nirS genes and nitrous oxide-reducing bacteria carrying the nos $Z$ gene (Schimel and Bennett, 2004; Levy-Booth et al., 2014). Thus, changes in these functional microorganisms can shed light on the underlying mechanisms of $\mathrm{N}$ transformation responses.
The abundance, composition and activity of these microbial functional groups largely depend on soil moisture, temperature, $\mathrm{O}_{2}$ diffusion, and $\mathrm{C}$ and $\mathrm{N}$ availabilities - all of these factors are strongly influenced by precipitation (Bell et al., 2014). For instance, previous research has shown that reduced precipitation decreases soil moisture and increases aeration and $\mathrm{O}_{2}$ diffusion, which stimulates the activity of nitrifiers $(A O A / A O B)$ and nitrification (Stark and Firestone, 1995; Zhalnina et al., 2012). In contrast, reduced precipitation could constrain the activity of denitrifiers, and consequently reduce the $\mathrm{N}_{2} \mathrm{O}$ and/or $\mathrm{N}_{2}$ emissions (Stark and Firestone, 1995; Zhalnina et al., 2012). Both denitrifiers and nitrifiers might be suppressed by decreased moisture and available $\mathrm{C}$ during drought (Bárta et al., 2010; Zhalnina et al., 2012). In addition, increased precipitation may raise the $\mathrm{NH}_{4}^{+}: \mathrm{NO}_{3}^{-}$ratio, as $\mathrm{NO}_{3}^{-}$is easily leached (Reichmann et al., 2013). High $\mathrm{NH}_{4}^{+}: \mathrm{NO}_{3}^{-}$ratios can consequently alter the predominant microbial groups (Nautiyal and Dion, 2008). The potential for mixotrophic growth and starvation tolerance of nitrifying communities (Levy-Booth et al., 2014) suggests a broader ecological niche occupied by the nitrifying groups. Therefore, the nitrifying and denitrifying microorganisms may respond differently to seasonal precipitation changes, leading to non-synchronous changes in nitrification and denitrification, and consequently different changes in soil $\mathrm{NO}_{3}^{-}, \mathrm{NH}_{4}^{+}$contents and $\mathrm{N}_{2} \mathrm{O}$ emission. However, the extent to which microorganisms control $\mathrm{N}$ transformations remains unclear because soil physicochemical properties can also affect $\mathrm{N}$ pools through erosion, leaching, plant uptake and physiological changes in microorganisms, regardless of microbial composition or abundance (Cregger et al., 2014; Auyeung et al., 2015). As a result, the effects of soil physicochemical properties and microbial communities on $\mathrm{N}$ transformation rates are difficult to differentiate, which makes it difficult to uncover the underlying drivers.

In order to investigate responses of $\mathrm{N}$ transformations to seasonal precipitation changes and the main controlling factors, a precipitation manipulation experiment was conducted in a subtropical forest in southern China, where the precipitation is predicted to increase in wet seasons and decrease in dry seasons (Zhou et al., 2011). We simulated this seasonal precipitation pattern for 2 years. Changes in soil physicochemical properties, net $\mathrm{N}$ transformation rates, and nitrifying (bacterial and archaeal amoA) and denitrifying (nirK, nirS and nosZ) gene abundance were analyzed and integrated in a hypothetical path model which assumed that the precipitation-induced changes in soil physicochemical properties and microbial abundance could alter $\mathrm{N}$ transformation rates (Fig. 1). The path coefficients and model fitness were analyzed by a structure equation model (SEM; Petersen et al., 2012; Delgado-Baquerizo et al., 2014). We hypothesized the following: (1) decreasing precipitation in the dry season will reduce $\mathrm{N}$ transformation rates by decreasing SWC, C and $\mathrm{N}$ 


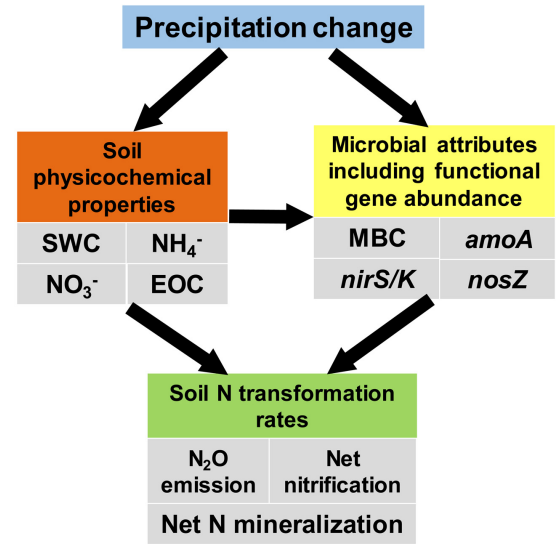

Figure 1. A conceptual model illustrating the effects of physicochemical properties and functional microorganisms on $\mathrm{N}$ transformation rates. Soil water content $(\mathrm{SWC})$, ammonium $\left(\mathrm{NH}_{4}^{+}\right)$, nitrate $\left(\mathrm{NO}_{3}^{-}\right)$and extractable organic carbon (EOC) concentrations were included in the group of soil physicochemical property. Microbial biomass carbon (MBC) and nitrifying (amoA) and denitrifying (nirK, nirS and nosZ) gene abundance were included in the microbial attributes group. The solid lines with arrows indicate the direction of the effect.

availabilities, as well as microbial abundance, but (2) precipitation addition during the wet season will have little impact on $\mathrm{N}$ transformation due to the originally sufficient SWC and substrate supply; (3) the responses of $\mathrm{N}$ transformation rates to the precipitation change will be associated with changes in functional gene abundance, because $\mathrm{N}$ transformation processes are primarily catalyzed by specific enzymes coded by functional genes; and (4) microbial abundance is directly influenced by soil physicochemical properties, but denitrifiers will be more strongly affected than nitrifiers, because the nitrifiers have the potential for mixotrophic growth and are tolerant of low $\mathrm{N}$ and $\mathrm{C}$ substrate availabilities.

\section{Materials and methods}

\subsection{Site description}

The study site is located at the Heshan National Field Research Station of Forest Ecosystem, Chinese Academy of Sciences $\left(22^{\circ} 41^{\prime} \mathrm{N}, 112^{\circ} 54^{\prime} \mathrm{E}\right)$, Heshan City, Guangdong province, southern China. This area has a pronounced wet season (April to September) receiving $80 \%$ of the annual rainfall, and a dry season (October to March) with only $20 \%$ of the annual rainfall (Wang et al., 2009). The soil is typical laterite (or Oxisols based on the USDA soil taxonomy), developed from sandstone, and is easily leached. This study was conducted in a 35-year old evergreen broadleaved mixed species forest dominated by Schima superba and Michelia macclurei. The vegetation inventory was conducted in the study forest by recording species name, diameter at breast height (DBH), tree height and density prior to the experiment. Overall, the forest consists of about 30 woody species, with average tree height of $8 \mathrm{~m}$, average DBH of $9.5 \mathrm{~cm}$, stem density of 1430 trees ha ${ }^{-1}$ and basal area of $11.6 \mathrm{~m}^{2} \mathrm{ha}^{-1}$.

\subsection{Experimental design}

A replicated manipulative experiment of precipitation reduction in the dry season and precipitation addition in the wet season was employed for 2 years from October 2012 to September 2014. Eight $12 \mathrm{~m} \times 12 \mathrm{~m}$ experimental plots were randomly assigned to four replicates of each of the two treatment types: the seasonal precipitation change manipulation (hereafter "precip-change") and the trenched control (hereafter "control"). Distance between the adjacent plots was at least $2 \mathrm{~m}$. Prior to the experiment, the stand characteristics between the precip-change and control plots were compared, and no significant differences were detected. Generally, the four precip-change plots have average tree height and DBH of $10.2 \pm 5.0 \mathrm{~m}$ and $10.7 \pm 6.3 \mathrm{~cm}$, respectively, with average crown width of $46 \pm 11 \mathrm{~m}^{2}$ and total number of 64 tree individuals. The average tree height, $\mathrm{DBH}$, crown width and total tree number in the four control plots are $7.7 \pm 3.5 \mathrm{~m}, 9.5 \pm 5.2 \mathrm{~cm}, 49 \pm 13 \mathrm{~m}^{2}$ and 68 , respectively. Around the perimeter of each of the eight plots, a $60-80 \mathrm{~cm}$ deep trench was excavated and $1 \mathrm{~m}$ height PVC segregation board was imbedded to reduce the potential for lateral movement of soil water from the surrounding areas into the plots. The precipitation reduction and addition was realized by throughfall exclusion and water addition facilities, respectively. Throughfall exclusion and water addition facilities were established in the 4 precip-change plots, but not in the control. The facilities included supporting structures, rainout shelters and water addition subsystems (Fig. S1 in the Supplement). Within each of the four precip-change plots, 16 galvanized steel pipes $(2.5-3 \mathrm{~m}$ length $\times 10 \mathrm{~cm}$ diameter) were vertically fixed in concrete bases which were imbedded in soil for $60 \mathrm{~cm}$ depth, and were welded together with 8 horizontal stainless steel frames $(12 \mathrm{~m}$ length) at the top. Rainout sheets were fixed in two stainless steel frames and hung on the supporting system with steel hook rivets. There were about 8-12 rainout sheets (with a width of $50-100 \mathrm{~cm}$ ) within each precip-change plot, depending on the density of tree stems. The rainout sheets were made from polyethylene plastic with $>90 \%$ light transmission and installed at approximately $1.5 \mathrm{~m}$ height above the soil surface. The total area of all the rainout sheets was $67 \%$ of the plot area (i.e., $144 \mathrm{~m}^{2}$ ). The sheets were opened to exclude throughfall during the dry season (1 October to 31 March) but folded without throughfall exclusion during the wet season (1 April to 30 September). Therefore, we reduced about $67 \%$ of the full incoming throughfall in the dry season. The intercepted rainfall was routed into an iron gutter placed at the lower slope of the plots, and then drained outside the plot with PVC pipes. 
The water added into precip-change plots in the wet season was pumped from a pond (about $800 \mathrm{~m}$ away from the experimental plots) and transported with PVC pipes to the rubber sacs fixed on the supporting system, and then sprinkled out via 25 sprinklers distributed evenly in each plot. The $\mathrm{pH}$ was similar in the throughfall (6.42) and pond water (6.19) but the nutrient (e.g., nitrogen and organic carbon) contents were higher in throughfall than in the pond water (Zhao et al., 2017), which ensures that we did not enrich nutrients while adding water. The amount of water added into a precip-change plot during the wet season was calculated as a product of the above-canopy dry-season rainfall, the throughfall ratio, and the throughfall exclusion ratio (i.e., 0.67). The above-canopy rainfall was obtained from a standard meteorological station (Davis, Vaisala, Finland) about $80 \mathrm{~m}$ away from the experimental site. The throughfall ratio was 0.86 , obtained from 8 rain gauges (TB4MM, Techno Solutions, Beijing, China) installed about $80 \mathrm{~cm}$ above soil surface in the eight plots. As a result, the intensity of the dry season rainfall events was reduced and the frequency of large rainfall events in wet season was increased, while the annual total quantity of the throughfall was not changed. More specifically, the throughfall excluded was $220 \mathrm{~mm}$ in the 2013 dry season (1 October 2012 to 31 March 2013) and the same amount of water was added back into each precip-change plot with four large events $\left(55 \mathrm{~mm} \mathrm{day}^{-1}\right)$ in June through September 2013 (i.e., one event in each month) to mimic the projected occurrence of more large rainfall events in the wet season in the region (Zhou et al., 2011). The throughfall exclusion was $170 \mathrm{~mm}$ in the 2014 dry season (1 October 2013 to 31 March 2014) and the same amount of water was added back into each precip-change plot with three large events $\left(57 \mathrm{~mm} \mathrm{day}^{-1}\right)$ in June through August 2014 (Fig. 2a).

\subsection{Soil sampling and analyses}

Soil samples were collected at the beginning and end of January, March, May, August and October from May 2012 to September 2014 for physicochemical properties, and from January 2013 to September 2014 for microbial functional genes analyses. Soil samples were collected from 0 to $10 \mathrm{~cm}$ depth with an auger ( $\Phi 35 \mathrm{~mm})$, sieved through a $2 \mathrm{~mm}$ mesh to remove litter and stones. One composite soil sample, consisting of six subsamples randomly collected within each plot, was used for the physicochemical (stored at $4{ }^{\circ} \mathrm{C}$ ) and microbial (stored at $-20^{\circ} \mathrm{C}$ ) analyses. All samples were analyzed within 2 weeks.

Soil physicochemical properties were measured using the methods as described by Liu et al. (1996). Briefly, soil water content (SWC) was obtained by drying fresh soils in an oven at $105^{\circ} \mathrm{C}$ for $24 \mathrm{~h}$. Total nitrogen (TN) and total phosphorus (TP) were determined using the $\mathrm{H}_{2} \mathrm{SO}_{4}$ digestionindophenol blue colorimetry and $\mathrm{H}_{2} \mathrm{SO}_{4}$ digestion-Mo$\mathrm{Sb}$ colorimetry methods, respectively. $\mathrm{NH}_{4}^{+}$and $\mathrm{NO}_{3}^{-}$contents were determined from the $2 \mathrm{M} \mathrm{KCl}$ extraction liquid by using the indophenol blue colorimetry and copperized cadmium reduction methods, respectively.

Soil extractable organic carbon (EOC) and microbial biomass carbon (MBC) were measured immediately after the soil sampling using the fumigation extraction method described in Vance et al. (1987). In detail, a pair of fresh soil subsamples $(10 \mathrm{~g})$ was placed into two glass breakers. One was fumigated in a vacuum dryer with alcohol-free chloroform and $\mathrm{NaOH}$ solution for $24 \mathrm{~h}$ in the dark, and the other one was placed in the dark for $24 \mathrm{~h}$ without fumigation. The two subsamples were extracted with $0.5 \mathrm{M} \mathrm{K}_{2} \mathrm{SO}_{4}$ after fumigation, and the EOC concentration was determined using a total organic $\mathrm{C}$ analysis instrument (TOC-VCSH, Shimadzu, Japan). The difference in EOC concentration between the fumigated and un-fumigated was multiplied by 0.45 to calculate MBC content.

Soil total DNA was extracted from $0.3 \mathrm{~g}$ fresh soil using the HiPure Soil DNA Mini Kit (Magen, Guangzhou, China), quantified with a NanoDrop 2000 spectrophotometer (Thermo Fisher Scientific Inc., USA) and stored at $-20^{\circ} \mathrm{C}$ for further analyses. The abundance of bacterial and archaeal ammonia monooxygenase gene $(a m o A)$, nitrite reductase genes (nirK and nirS) and nitrous oxide reductase gene (nos $Z$ ) were quantified by using absolute real-time polymerase chain reaction (PCR) on an ABI 7500 thermocycler system with primers and thermal profiles presented in the Supplement (Table S1). The real-time PCR reactions were performed on 96-well plates (Axygen, USA), with $20 \mu \mathrm{L}$ volume in each well including $12.5 \mu \mathrm{L}$ SYBR Premix Ex Taq (TaKaRa Biotechnology, Japan), $1 \mu \mathrm{L}$ of each primer (10 $\left.\mathrm{mmol} \mathrm{L}^{-1}\right), 2 \mu \mathrm{L}$ of DNA template $(10 \mathrm{ng}), 1 \mu \mathrm{L}$ dimethyl sulfoxide and $4.5 \mu \mathrm{L}$ RNase free Ultra-Pure water. The standards were constructed using the method described in Henry et al. (2006) and Isobe et al. (2012). Briefly, the target functional gene PCR products were obtained with the same primers used in real-time PCR and the extracted soil DNA as template. The PCR products were cloned using the pMD20$\mathrm{T}$ vector (TaKaRa, Dalian Division), and then transformed into Escherichia coli JM109 strains. The recombinant Escherichia coli JM109 strains carrying the target functional gene recombinant plasmids were inoculated into LB broth with ampicillin and incubated at $37^{\circ} \mathrm{C}$ overnight. The plasmid DNA was then extracted using the HiPure Plasmid Mini Kit (Magen, Guangzhou, China) and quantified on a NanoDrop 2000 spectrophotometer (Thermo Fisher Scientific Inc., USA). The DNA copy numbers of the extracted plasmid DNA carrying the target functional gene was calculated from the plasmid DNA size, concentration and average base pair molecular weight, which could stand for the copy numbers of the standard functional gene. Finally, the standard curve was generated from a tenfold serial dilution $\left(10^{3}-10^{8}\right.$ copies per $\mu \mathrm{L}$ ) of the plasmid DNA. 


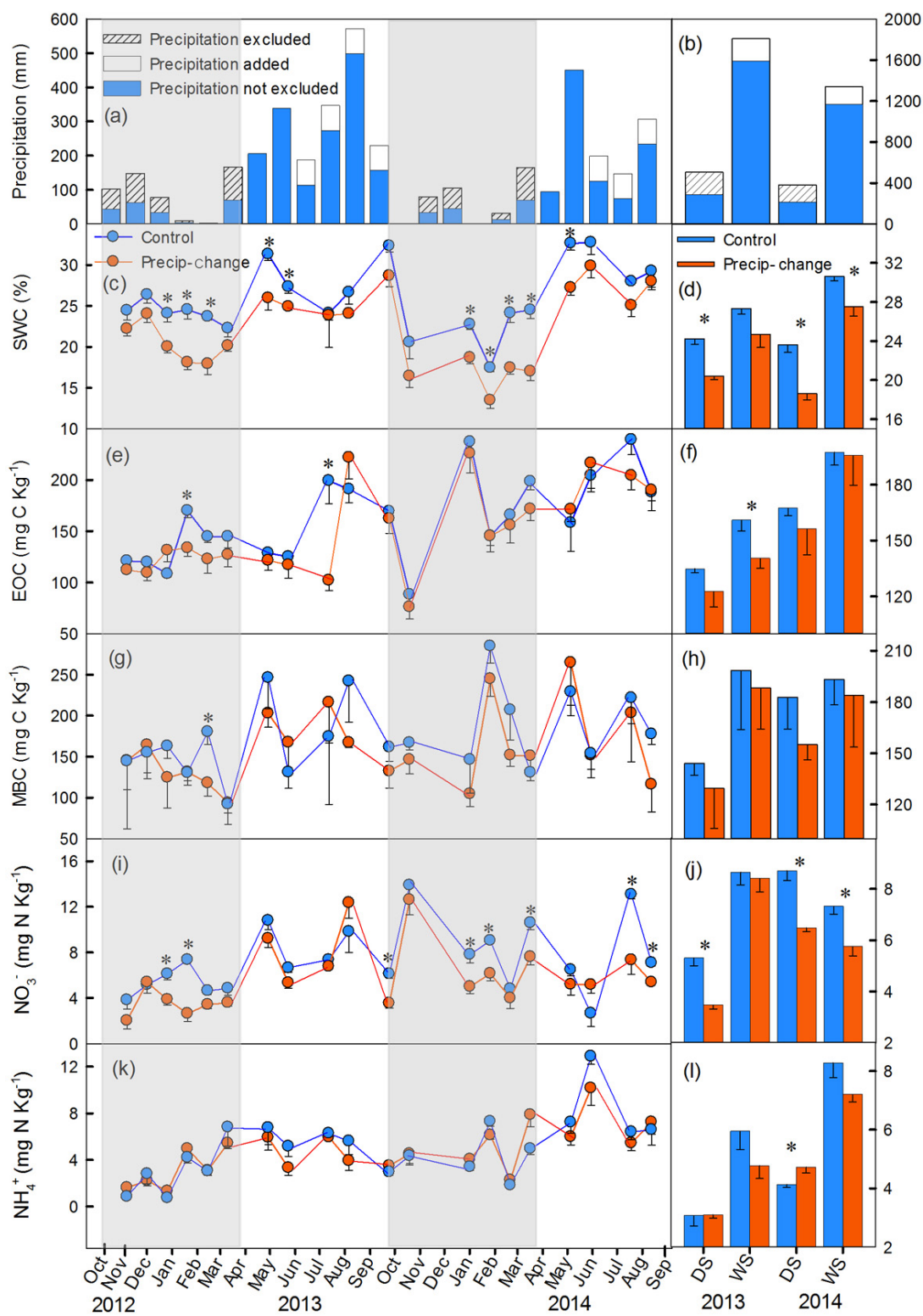

Figure 2. Seasonal dynamics of precipitation and soil physicochemical properties in control and precipitation change (precip-change) plots over the course of experiment. Points and bars with standard error $(n=4)$ show mean values at each sampling time and in dry (DS) and wet (WS) seasons. Grey shades indicate the periods of precipitation reduction. The significance levels are presented as $* p<0.05$.

\subsection{Measurement of $\mathrm{N}$ transformation rates}

Net $\mathrm{N}$ mineralization and nitrification rates were measured through the in situ soil incubation using the resin-core method (Reichmann et al., 2013). Six paired soil cores (0$10 \mathrm{~cm}$ ) were randomly sampled within each plot at the beginning of January, March, May, August and October from May 2012 to September 2014. One core of each pair was sieved through a $2 \mathrm{~mm}$ sieve after removing litter and stones, and stored at $4{ }^{\circ} \mathrm{C}$ for the initial pre-incubation measurements of SWC, $\mathrm{NO}_{3}^{-}$and $\mathrm{NH}_{4}^{+}$. The other core was incubated for 1 month in a PVC pipe that was open on both sides and was oriented vertically with an ion exchange resin bag placed at the bottom to collect inorganic $\mathrm{N}$ leached from the core. Soil cores and resin bags in the PVC pipes were collected after the 1 month incubation, and the soil was sieved and stored at $4^{\circ} \mathrm{C}$ for the final post-incubation measurements of SWC, $\mathrm{NO}_{3}^{-}$and $\mathrm{NH}_{4}^{+}$. The net $\mathrm{N}$ mineralization rate was calculated as the final $\mathrm{NO}_{3}^{-}$and $\mathrm{NH}_{4}^{+}$content minus the initial $\mathrm{NO}_{3}^{-}$and $\mathrm{NH}_{4}^{+}$content, and the net nitrification rate was calculated as the final $\mathrm{NO}_{3}^{-}$content minus the initial $\mathrm{NO}_{3}^{-}$content (Reichmann et al., 2013). Concentrations of $\mathrm{NO}_{3}^{-}$and $\mathrm{NH}_{4}^{+}$ex- 
tracted from the resin were considered as the leaching rates of $\mathrm{NO}_{3}^{-}$and $\mathrm{NH}_{4}^{+}$per month.

Soil nitrous oxide $\left(\mathrm{N}_{2} \mathrm{O}\right)$ efflux was measured twice per month, from October 2012 to September 2014, using static chamber and gas chromatography techniques. The static chambers were made from white PVC materials and consisted of a removable cover box $(26 \mathrm{~cm}$ diameter $\times 35 \mathrm{~cm}$ height $)$ and a base $(33 \mathrm{~cm}$ diameter $\times 11 \mathrm{~cm}$ height $)$. The bottom of the base was inserted into soil at a depth of $5 \mathrm{~cm}$. Two months before gas sampling, four static chambers were deployed randomly at each plot to minimize effects of installation disturbance. The $\mathrm{N}_{2} \mathrm{O}$ samples were collected between 09:00 and 11:00 LT. The static chamber was closed for $30 \mathrm{~min}$, and gas samples $(80 \mathrm{~mL})$ were taken using $100 \mathrm{~mL}$ plastic syringes at the initial closed time as well as every $10 \mathrm{~min}$ thereafter during the closed period. At the same time, values of atmospheric pressures and air temperatures inside static chambers were measured 3 times. $\mathrm{N}_{2} \mathrm{O}$ concentrations were analyzed in the laboratory with a gas chromatograph (Agilent 7890A, Agilent Technologies, USA) equipped with an electron capture detector set at $300^{\circ} \mathrm{C}$ and a stainless porapak-Q column set at $70^{\circ} \mathrm{C}$ within $24 \mathrm{~h}$ after gas sampling. The $\mathrm{N}_{2} \mathrm{O}$ flux was calculated by changes in the $\mathrm{N}_{2} \mathrm{O}$ concentrations inside static chamber during periods of gas sampling, with the equation as follows:

$F=\rho \times \frac{V}{A} \times \frac{P}{P_{0}} \times \frac{T_{0}}{T} \times \frac{\mathrm{d} C}{\mathrm{~d} t}$,

where $F$ stands for the flux of $\mathrm{N}_{2} \mathrm{O}\left(\mathrm{mg} \mathrm{m}^{-2} \mathrm{~h}^{-1}\right), \rho$ stands for the density of $\mathrm{N}_{2} \mathrm{O}$ under standard condition $\left(\mathrm{g} \mathrm{L}^{-1}\right), V$ stands for the effective volume of chamber $\left(\mathrm{m}^{3}\right), A$ stands for the area of soil covered by chamber $\left(\mathrm{m}^{2}\right), P$ and $T$ stand for the atmospheric pressures $(\mathrm{Pa})$ and absolute air temperature inside chamber $(\mathrm{K})$ when gas sampling, $P_{0}$ and $T_{0}$ stand for the atmospheric pressures $(\mathrm{Pa})$ and the absolute temperature $(\mathrm{K})$ under standard condition, and $\mathrm{d} C / \mathrm{d} t$ stands for changes of $\mathrm{N}_{2} \mathrm{O}$ concentrations in the chamber during gas sampling.

\subsection{Statistical analyses}

Two-way repeated-measure analysis of variance (ANOVA) with sampling time as the repeated factor was used to examine the effects of precip-change and sampling time on all measured parameters. Pillai's trace from multivariate testing was used for within-subject testing when the assumption of multisample sphericity was not met. Independent-sample $t$ tests were used to detect the difference of each variable between precip-change and control at each sampling time. All the parameters were explored for normality (KolmogorovSmirnov test) and homogeneity of variances (Levène test) prior to the analyses, and log-transformed if necessary. All statistical analyses described above were performed using SPSS v.16.0 (SPSS Inc., Chicago, IL, USA).

Structural equation modeling (SEM) is often used to detect complex relationships between one or more dependent or in- dependent variables by using a series of statistical methods. The complex relationships among the target variables are expressed as paths in a hypothetical model, and finally tested by a series of statistical methods, such as univariate and multivariate regressions, ANOVA and factor analysis (Bagozzi and Yi, 2012). In this study, we used SEM to test the hypothetical causal relationships among soil physicochemical properties, microbial abundance and $\mathrm{N}$ transformation rates in the conceptual model (Fig. 1), and the SEM was performed with AMOS 21.0 (SPSS Inc., Chicago, IL, USA). How the effects of soil physicochemical properties and microbial abundance determine the responses of $\mathrm{N}$ transformation rates were evaluated. In order to explicitly illustrate the pathways of soil physicochemical properties and microbial abundance involved in each $\mathrm{N}$ transformation process, three individual models were constructed corresponding to the conceptual model to explain the responses of (a) net nitrification, (b) net $\mathrm{N}$ mineralization and (c) $\mathrm{N}_{2} \mathrm{O}$ emission rates. The hypothetical relationships among variables in the models are constructed based on the results of correlation analyses (Fig. S2). We used three models since it would be easier to discover the controlling factors than using one complex model that implicates all the measured processes (DelgadoBaquerizo et al., 2014). In these models, the precip-change treatments are categorical exogenous variables with two levels: 0 representing control and 1 representing seasonal precipitation changes (Delgado-Baquerizo et al., 2014). Abundance of both nirK and nirS genes were shown to be correlated with nitrification or $\mathrm{N}$ mineralization rates (Levy-Booth et al., 2014). Therefore, nirK and nirS abundance were added as one $(n i r K+n i r S)$ endogenous factor in the model. Net nitrification rate was included in model (b) as an endogenous factor because it may influence $\mathrm{N}_{2} \mathrm{O}$ emission through altering the production of $\mathrm{NO}_{3}^{-}$as the substrate for $\mathrm{N}_{2} \mathrm{O}$ production. Prior to the SEM analyses, normal distribution of all the involved variables were examined, and gene abundances were log-transformed. Goodness of model fits was evaluated by chi-square test $(p>0.05)$, comparative fit index (CFI $>0.95$ ), and root mean square errors of approximation (RMSEA < 0.05) (Hu and Bentler, 1998; Schermelleh-Engel et al., 2003). Pathways without significant effects were not shown $(p>0.05)$ in the final models.

\section{Results}

\subsection{Responses of soil physicochemical properties, $N$ transformation rates and microbial abundance to precipitation changes}

Before the precipitation manipulation from May to September in 2012, average net $\mathrm{N}$ transformation (i.e., $\mathrm{N}$ nitrification, mineralization and leaching) rates, $\mathrm{N}\left(\mathrm{NO}_{3}^{-}, \mathrm{NH}_{4}^{+}\right.$, $\mathrm{TN})$ and organic $\mathrm{C}$ (MBC, EOC, TOC) contents as well as soil temperature were similar among all plots (Table S2). In 


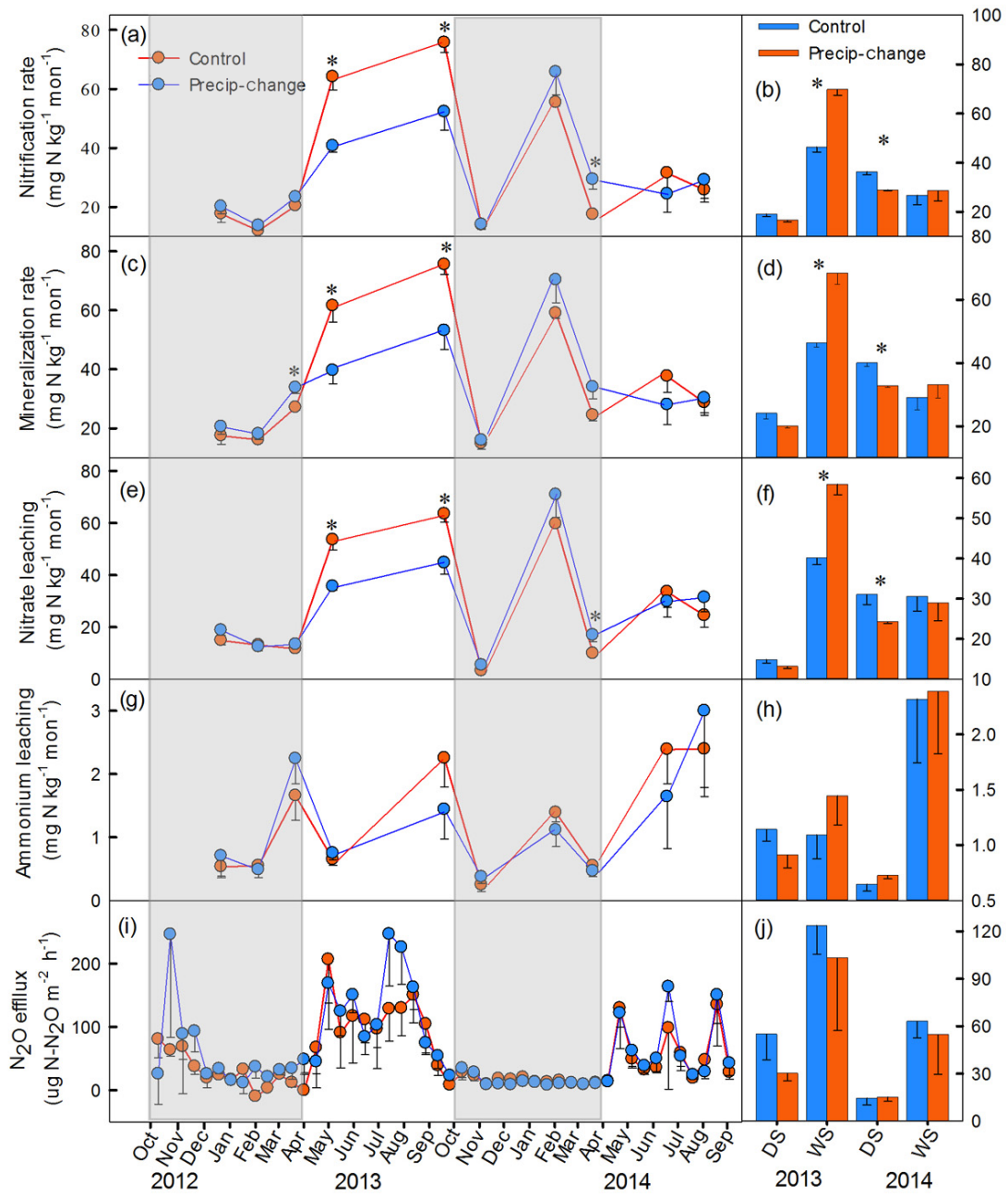

Figure 3. Nitrogen transformation rates measured in control and precipitation change (precip-change) plots over the course of experiment. Points and bars with standard error $(n=4)$ show mean values at each sampling time and in dry (DS) and wet (WS) seasons. Grey shades indicate the periods of precipitation reduction. The significance levels are presented as $* p<0.05$.

the two dry seasons with precipitation reduction, SWC decreased by $16 \%$ in 2013 and by $21 \%$ in $2014(p<0.01$; Table $\mathrm{S} 3$ and Fig. 2d). Similarly, $\mathrm{NO}_{3}^{-}$concentration decreased by 35 and $24 \%$ in 2013 and 2014, respectively $(p<0.01$; Table S3 and Fig. 2j). Opposite patterns were observed for $\mathrm{NH}_{4}^{+}$ concentration, which increased with the precipitation reduction (Fig. 21). In the wet seasons with precipitation addition, $\mathrm{SWC}, \mathrm{NO}_{3}^{-}$concentration, $\mathrm{EOC}$ and $\mathrm{MBC}$ remained lower in the precip-change plots than in the control plots in both years (Table S3 and Fig. 2d, f, h and j). After the experiment, soil $\mathrm{pH}$ in the precip-change plots was $3.82 \pm 0.02$ in dry seasons and $3.78 \pm 0.07$ in wet seasons. In the control plots, it was $4.06 \pm 0.05$ in dry and $3.86 \pm 0.1$ in wet seasons. It has no significant changes when compared with the $\mathrm{pH}$ values before the experiment, with $4.01 \pm 0.04$ and $4.05 \pm 0.08$ in dry and wet seasons of the precip-change plots, and $4.23 \pm 0.01$ and $4.11 \pm 0.07$ in dry and wet seasons of the control plots.
Precipitation reduction strongly decreased the average dry-season net nitrification rate by $13 \%$ in 2013 and by $20 \%$ in 2014 , and decreased net $\mathrm{N}$ mineralization rate by $16 \%$ in 2013 and by $18 \%$ in 2014 ( $p<0.1$; Table S4 and Fig. $3 b$ and d). The $\mathrm{NO}_{3}^{-}$leaching also declined with precipitation reduction, especially in 2014, with a marked decrease by $22 \%$ $(p<0.001$; Table S4 and Fig. 3e and f). Contrastingly, the rates of three $\mathrm{N}$ transformation processes increased by $50 \%$ with precipitation addition in the 2013 wet season, whereas they changed little in the 2014 wet season (Fig. 3b, d and f). Throughout the 2 years, moderate decreases were detected in $\mathrm{N}_{2} \mathrm{O}$ emission either during dry-season precipitation reduction $(35 \%)$ or during wet-season precipitation addition (15\%) (Table S4 and Fig. 3j).

No amplification of the bacterial $a m o A$ gene was detected in soil, either from the precip-change plots or from the control plots, which was mainly because soil $A O B$ community abundance in the studied forest was under the detec- 


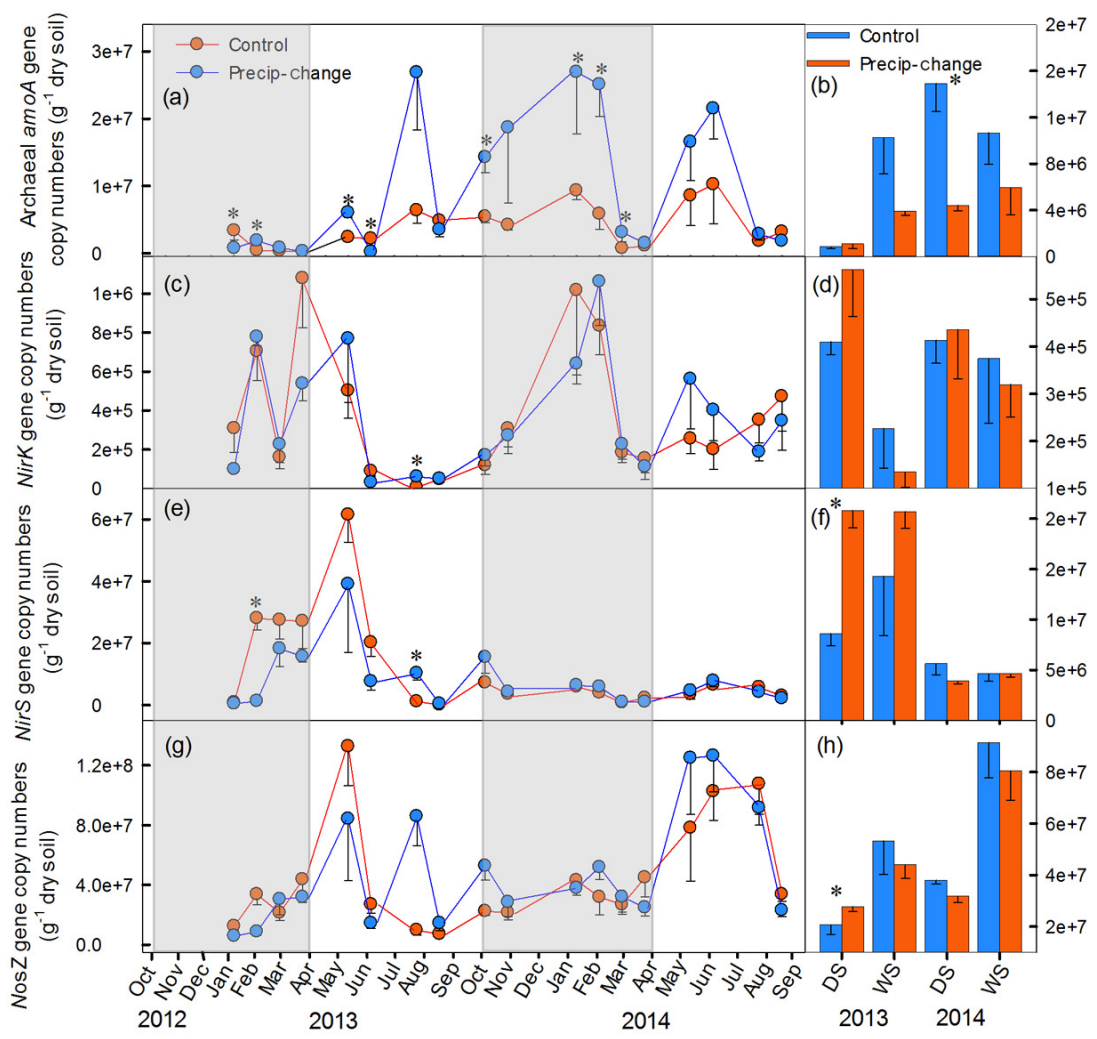

Figure 4. Copy numbers of archaeal amoA, nirK, nirS and nosZ gene per gram of dry soil measured in control and precipitation change (precip-change) plots over the course of experiment. Points and bars with standard error $(n=4)$ show mean values at each sampling time and in dry (DS) and wet (WS) seasons. Grey shades indicate the periods of precipitation reduction. The significance levels are presented as $* p<0.05$.

tion limitation caused by low soil $\mathrm{pH}(4.08 \pm 0.05)$ (Isobe et al., 2012). The average seasonal archaeal amoA gene was $6.5 \times 10^{6} \pm 1.9 \times 10^{6}$ copies $^{-1}$ dry soil, and varied significantly according seasonal precipitation changes. With precipitation reduction, the archaeal amoA gene abundance changed little in the 2013 dry season but decreased by $70 \%$ in the 2014 dry season (Fig. 4a and b). The abundance of three denitrifying genes (nirK, nirS and nosZ) increased with precipitation reduction by $30-80 \%$ in the 2013 dry season $(p<0.05$; Table S5 and Fig. 4d, $\mathrm{f}$ and $\mathrm{h}$ ). In both seasons of 2014, neither dry-season precipitation reduction nor wetseason precipitation addition had significant impacts on the abundance of the three denitrifying genes (Table S5 and Fig. 4c, d, e, f, g and h).

\subsection{Paths determining $\mathbf{N}$ transformation rates and functional microbial abundance}

Although the annual precipitation amount was kept constant, the redistribution of seasonal precipitation imposed an overall negative impact on $\mathrm{SWC}$ and $\mathrm{NO}_{3}^{-}$concentration (Fig. 5). SWC affected net nitrification and $\mathrm{N}$ mineralization through a direct negative path and $\mathrm{N}_{2} \mathrm{O}$ emission through a direct positive path (Fig. 5). Net $\mathrm{N}$ mineralization, nitrification and
$\mathrm{N}_{2} \mathrm{O}$ emission rates were also affected by the functional-gene abundance and MBC paths. Since the bacterial amoA gene was not detected, we only use the archaeal amoA abundance as the dominant nitrifying microbial abundance in the SEM analyses. Specifically, the archaeal amoA gene abundance and $\mathrm{MBC}$ had direct positive impacts on net $\mathrm{N}$ mineralization and nitrification rates, whereas the nos $Z$ gene abundance had a direct negative impact on $\mathrm{N}_{2} \mathrm{O}$ emission (Fig. 5). As a result, 21 and $22 \%$ of the net $\mathrm{N}$ mineralization and nitrification variability are explained, respectively (see the $r^{2}$ in Fig. 5a and b). Among the direct influential factors, archaeal amoA abundance showed the strongest correlations, with both net $\mathrm{N}$ mineralization or with net nitrification rates. Soil $\mathrm{N}_{2} \mathrm{O}$ emission was mostly affected by positive effects of net nitrification rate and SWC, followed by negative effects of nos $Z$ abundance and MBC, and as much as $42 \%$ of the total variation could be explained (see the $r^{2}$ in Fig. 5c).

Precip-change-induced changes in SWC had no direct impacts on functional-gene abundance. Instead, the functionalgene abundance was indirectly affected by the precipchange-induced alterations in $\mathrm{NO}_{3}^{-}, \mathrm{NH}_{4}^{+}$concentrations and EOC (Fig. 5). Specifically, $\mathrm{NO}_{3}^{-}$and $\mathrm{NH}_{4}^{+}$had direct positive effects on archaeal amoA abundance, whereas EOC had 
(a)

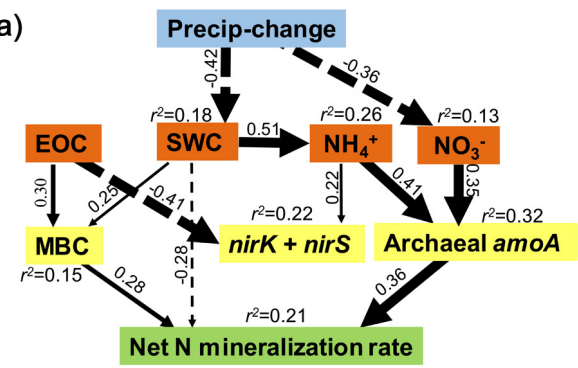

(b)

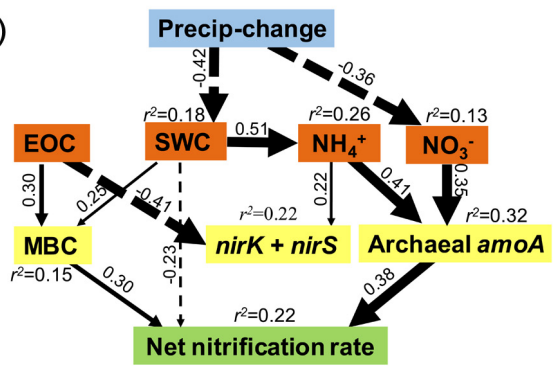

(c)

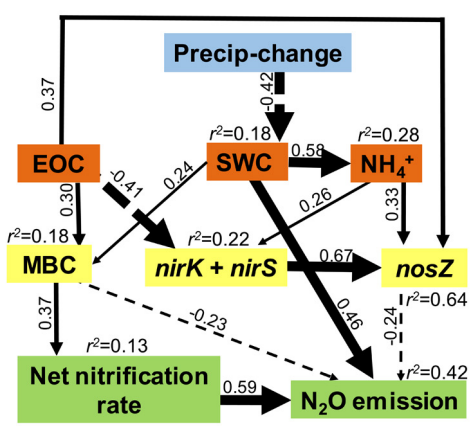

Figure 5. Path diagrams demonstrating the effects of soil physicochemical properties and functional-gene abundance on net nitrification, $\mathrm{N}$ mineralization and $\mathrm{N}_{2} \mathrm{O}$ efflux rates in response to precipitation change (precip-change) over 2 years. Numbers adjacent to arrows are path coefficients, which indicate the relationships between the two variables on both sides of the arrows. Solid and dashed lines represent positive and negative paths, respectively. The $r^{2}$ above or below each response variable in the model denotes the proportion of variance which could be explained. The size of the lines indicates significant levels of path coefficients.

a direct negative effect on nirK + nirS abundance. Both $\mathrm{NH}_{4}^{+}$ and EOC concentration had direct positive impacts on the nosZ abundance (Fig. 5c). Changes in MBC were directly positively influenced by SWC and EOC.

\section{Discussion}

\subsection{Drivers of $\mathbf{N}$ transformation processes}

Consistent with our hypotheses, seasonal precipitation redistribution induced significant changes in net $\mathrm{N}$ mineralization and nitrification rates by altering SWC, MBC and archaeal amoA gene abundance. $\mathrm{N}_{2} \mathrm{O}$ emission was decreased by both precipitation enhancement (wet season) and precipitation reduction (dry season), which indicated that soil $\mathrm{N}$ loss by $\mathrm{N}_{2} \mathrm{O}$ emission in subtropical forests would be alleviated by the predicted seasonal precipitation changes. In contrast, increased $\mathrm{NO}_{3}^{-}$leaching during precipitation addition in the wet seasons led to significant losses from the soil $\mathrm{NO}_{3}^{-}$ pool. During the 2 year experiment, SWC was always lower in precip-change plots than in control plots, despite the precipitation addition in the wet seasons (Fig. $2 \mathrm{c}$ and d). One reason for this is the higher transpiration loss resulting from relatively bigger trees in the precip-change plots (tree height: $10.2 \pm 5.0 \mathrm{~m}$, DBH: $10.7 \pm 6.3 \mathrm{~cm}$ ) than that in the control plots (tree height: $7.7 \pm 3.5 \mathrm{~m}, \mathrm{DBH}: 9.5 \pm 5.2 \mathrm{~cm}$ ). There were no significant differences in these stand characteristics, but the bigger trees in precip-change plots might have had greater transpiration rates and therefore caused more soil water loss in the summer wet season (Gao et al., 2017). Another reason might be the large amount of precipitation added (55 $\mathrm{mm}$ per event). Large precipitation events may result in flood-irrigation that can break the soil pores or reduce pore number, leading to soil structural decline (Barber et al., 2001). These changes in soil structure may affect soil water content, as soil water retention capacity is related to pore size and pore distribution (Loll and Moldrup, 2000).

Initially, we hypothesized that decreased precipitation in the dry season would suppress $\mathrm{N}$ transformation, and precipitation addition during the wet season would have little impact on $\mathrm{N}$ transformation processes because the soils are watersaturated and substrate sufficient. In agreement with the first hypothesis, net nitrification and $\mathrm{N}$ mineralization rates decreased sharply with the reduction of throughfall in the dry season (Fig. 3a, b, c and d). However, contrary to the second hypothesis, nitrification and $\mathrm{N}$ mineralization rates increased markedly with precipitation supplementation in the wet seasons (Fig. 3a, b, c and d). These results can be explained by the interactions between microbial abundance, soil moisture and substrate availability (Figs. 5a, b and S3). Specifically, soil EOC of the dry season was less in the precip-change plots than in the control plots (Fig. 2e and f), which is probably attributable to reduced $\mathrm{C}$ input due to lower root production and exudation after drying (Kuzyakov and Domanski, 2000; Borken and Matzner, 2009). The reduced supply of soil C substrate (i.e., EOC) could have restricted the growth of soil microorganisms (e.g., MBC and $A O A$ ), resulting in decreased net nitrification and mineralization rates (Fig. 5a and b). Although increased $\mathrm{NH}_{4}^{+}$concentrations with reduced precipitation could provide more $\mathrm{N}$ substrate for nitrifiers, the negative effects of decreased SWC and EOC may have outweighed the positive effects of increased $\mathrm{NH}_{4}^{+}$. Instead, the accumulated $\mathrm{NH}_{4}^{+}$after dry season precipitation reduction might have had a positive legacy effect on soil microbial activity in the wet season, leading to increased $\mathrm{N}$ transformations. In addition, SWC differences are also known to directly affect $\mathrm{N}$ transformations by stimulating physiological 
changes in microbial activity, regardless of microbial abundance and composition (Auyeung et al., 2015). The increased $\mathrm{N}$ transformation rates (Fig. 3b, d) in response to decreased SWC, MBC (Fig. 2d, h) and archaeal amoA gene abundance (Fig. 4a) with precipitation addition might be such a case (also see Fig. S2). A $10 \%$ lower SWC in the precip-change plots in natural humid wet season might create better redox conditions for microbial nitrification, as excessive soil moisture could reduce soil oxygen concentration. According to Borken and Matzner (2009), the increases of soil microbial activity by rewetting usually occurred due to an increased pulse in organic substrate availability as well as reconstituting mineralization of SOM. Substantial decreases in MBC and archaeal amoA gene abundance in our study indicated that some microorganisms may die from starvation or competition caused by limited substrate concentrations, and consequently release $\mathrm{MBC}$ and microbial biomass nitrogen (MBN). These available substrates released by dead microorganisms could be reused by the surviving microorganisms, which could support the increased energy demand of accelerated microbial processes (Borken and Matzner, 2009).

We also hypothesized that $\mathrm{N}$ transformation processes are associated with functional microbial abundance. As expected, net $\mathrm{N}$ mineralization and nitrification rates showed stronger relationships with archaeal amoA abundance than with $\mathrm{MBC}$ or other soil properties (Fig. 5a and b). However, $\mathrm{MBC}$ and denitrifying gene abundance had similar effects on $\mathrm{N}_{2} \mathrm{O}$ emission. Our results also showed that only nos $Z$ gene abundance exerted a pronounced effect on $\mathrm{N}_{2} \mathrm{O}$ emission (Fig. 5c), probably by reducing $\mathrm{N}_{2} \mathrm{O}$ consumption (Henderson et al., 2010; Levy-Booth et al., 2014). No significant correlation between $\mathrm{N}_{2} \mathrm{O}$ emission and nirK + nirS gene abundance was detected, in contrast to previous studies (Levy-Booth et al., 2014; Gao et al., 2016). The $\mathrm{N}_{2} \mathrm{O}$ emission-related denitrification can also be performed by nitrifiers and fungi in soils with high aeration and limited substrate availability (Levy-Booth et al., 2014). The experimental seasonal precipitation strongly decreased SWC and EOC content (Fig. 1), leading to higher aeration while lowering substrate availability. These changes in soil physicochemical properties could enhance the role of nitrifier and fungi denitrification in controlling $\mathrm{N}_{2} \mathrm{O}$ emission. In addition, SWC and nitrification rate also directly affected $\mathrm{N}_{2} \mathrm{O}$ emission by altering substrate availability and consequently microbial activity, despite high microbial abundance (Fig. 5c). Although functional microbial abundance showed the most significant correlations with $\mathrm{N}$ transformation rates and could explain more than $20 \%$ of their variation, a large proportion of the variation remained unexplained (Fig. 5). This unexplained variation is mainly attributed to the changes in other functional microbial genes involved in the nitrogen cycle, such as narG and napA responsible for $\mathrm{NO}_{3}^{-}$reduction, and nifH responsible for $\mathrm{N}$ fixation (Widmer et al., 1999; Tavares et al., 2006). Moreover, gene abundance based on DNA may not fully reflect gene expression.

\subsection{Determinants of nitrifying and denitrifying gene abundance}

The responses of both nitrifying and denitrifying genes were mainly related to the changes in substrate concentrations. SEM analysis showed that both amoA and nos $Z$ gene abundance was positively affected by EOC and $\mathrm{NH}_{4}^{+}$concentration, suggesting substrate constraints for these two functional microbial groups. This disagreed with previous studies that reported that the $A O A$ community had greater potential for mixotrophic growth and better low-substrate tolerance than its counterpart $A O B$ (Erguder et al., 2009; Shen et al., 2012). However, these previous results were mainly due to greater competitiveness of $A O A$ than $A O B$, as these studies mainly focused on the comparison of effects of substrate availability on $A O A$ and $A O B$ communities. Both nos $Z$ and amoA gene abundance increased with EOC and $\mathrm{NH}_{4}^{+}$concentration (Fig. 5), which indicated that the $A O A$ community could be constrained by $\mathrm{C}$ and $\mathrm{N}$ substrates when competing with other microbes that have different functions. Otherwise, the existing $A O A$ species that have the potential for mixotrophic growth and starvation tolerance would not dominate in the subtropical forest studied, as the soil is rich in SOM (Zhou et al., 2006; Chen et al., 2015). Therefore, the AOA community in the studied soil could be strongly influenced by changes in soil $\mathrm{C}$ and $\mathrm{N}$ availability.

The abundance of nirK and nirS genes was positively controlled by soil $\mathrm{NH}_{4}^{+}$concentration and negatively controlled by EOC content (Fig. 5). This confirmed that higher $\mathrm{NH}_{4}^{+}$ content could favor more abundant microorganisms containing nirK or nirS genes (Yi et al., 2015), because higher $\mathrm{NH}_{4}^{+}$ concentration could supply sufficient $\mathrm{NO}_{3}^{-}$as the direct substrate or provide optimum $\mathrm{pH}$ values for growth of the denitrifying microorganisms. The negative effect of EOC on nirK and nirS gene abundance was inconsistent with previous reports that denitrifiers are primarily heterotrophic (Bárta et al., 2010). One reason is that high EOC concentrations can constrain the growth of microorganisms carrying nirK and nirS genes through effects on other factors, such as $\mathrm{pH}$ and C: $\mathrm{N}$ ratio (Henderson et al., 2010; Levy-Booth et al., 2014). Generally, the abundance of both nitrifying and denitrifying genes changed with precipitation redistribution, and the direction and magnitude of the changes depended mainly on soil $\mathrm{N}$ and $\mathrm{C}$ substrate availabilities.

\section{Conclusion}

Soil net nitrification and $\mathrm{N}$ mineralization rates responded significantly to seasonal precipitation redistribution. More than $20 \%$ of the variation could be explained by the effects of microbial abundance, SWC, and soil $\mathrm{C}$ and $\mathrm{N}$ substrates. $A O A$ community abundance was the main factor in regulating these two $\mathrm{N}$ transformation processes. $\mathrm{N}_{2} \mathrm{O}$ emission during the 2 year experiment decreased moderately, and as much as 
$42 \%$ of the total variation in $\mathrm{N}_{2} \mathrm{O}$ emission was attributed to the combined effects of SWC, nitrification rate, $\mathrm{MBC}$ and nos $\mathrm{Z}$ gene abundance. The accumulation of $\mathrm{NH}_{4}^{+}$due to dryseason precipitation reduction may stimulate nitrification in the wet season, and consequently accelerate $\mathrm{N}$ loss by $\mathrm{NO}_{3}^{-}$ leaching. Therefore, the predicted long-term seasonal precipitation changes in subtropical forests may result in profound changes to different $\mathrm{N}$ pools and fluxes, including reduced $\mathrm{N}_{2} \mathrm{O}$ emission and enhanced $\mathrm{NO}_{3}^{-}$leaching. These, in turn, could exert a feedback to climate and environmental changes. Meanwhile, changes in functional microbial abundance induced by soil EOC and $\mathrm{NH}_{4}^{+}$substrate availabilities will determine the extent and direction of soil $\mathrm{N}$ transformation changes.

Data availability. All the relevant data are presented in the paper and supplementary materials.

\section{The Supplement related to this article is available online at doi:10.5194/bg-14-2513-2017-supplement.}

Author contributions. Jie Chen and Guoliang Xiao carried out the experiment, analyzed the data and wrote the draft paper. Weijun Shen conceived the study. All authors contributed to paper writing and revision.

Competing interests. The authors declare that they have no conflict of interest.

Acknowledgements. We thank Y. Lin, Z. Chen, M. Li and S. Fu for their help in the field; C. Long and X. Zhou for their help with laboratory assays; and $\mathrm{K}$. Mason-Jones for his help with the English revision. Three anonymous referees provided constructive comments that improved the paper. Financial support came from the Natural Science Foundation of China (31130011, 31425005 and 31290222) and the Natural Science Foundation of Guangdong Province, China (S2012020011084).

Edited by: D. Akob

Reviewed by: three anonymous referees

\section{References}

Auyeung, D. S. N., Martiny, J. B. H., and Dukes, J. S.: Nitrification kinetics and ammonia-oxidizing community respond to warming and altered precipitation, Ecosphere, 6, 83, doi:10.1890/es1400481.1, 2015.

Bagozzi, R. P. and Yi, Y.: Specification, evaluation, and interpretation of structural equation models, J. Acad. Market Sci., 40, 8-34, doi:10.1007/s11747-011-0278-x, 2012.
Barber, S. A., Katupitiya, A., and Hickey, M.: Effects of long-term subsurface drip irrigation on soil structure, Proceedings of the 10th Australian Agronomy Conference, The Regional Institute Online Publishing (http://www.regional.org.au/au/asa/2001/p/3/ barber.htm), Hobart, 2001.

Bárta, J., Melichová, T., Vaněk, D., Picek, T., and Šantrůčková, H.: Effect of $\mathrm{pH}$ and dissolved organic matter on the abundance of nirK and nirS denitrifiers in spruce forest soil, Biogeochemistry, 101, 123-132, doi:10.1007/s10533-010-9430-9, 2010.

Beier, C., Beierkuhnlein, C., Wohlgemuth, T., Penuelas, J., Emmett, B., Korner, C., de Boeck, H. J., Christensen, J. H., Leuzinger, S., Janssens, I. A., and Hansen, K.: Precipitation manipulation experiments - challenges and recommendations for the future, Ecol. Lett., 15, 899-911, doi:10.1111/j.14610248.2012.01793.x, 2012.

Bell, C. W., Tissue, D. T., Loik, M. E., Wallenstein, M. D., AcostaMartinez, V., Erickson, R. A., and Zak, J. C.: Soil microbial and nutrient responses to 7 years of seasonally altered precipitation in a Chihuahuan Desert grassland, Glob. Change Biol., 20, 16571673, doi:10.1111/gcb.12418, 2014.

Borken, W. and Matzner, E.: Reappraisal of drying and wetting effects on $\mathrm{C}$ and $\mathrm{N}$ mineralization and fluxes in soils, Glob. Change Biol., 15, 808-824, doi:10.1111/j.13652486.2008.01681.x, 2009.

Chen, J., Zhang, H., Liu, W., Lian, J. Y., Ye, W. H., and Shen, W. J.: Spatial distribution patterns of ammonia-oxidizing archaea abundance in subtropical forests at early and late successional stages, Sci. Rep., 5, 16587, doi:10.1038/Srep16587, 2015.

Chen, Y. T., Bogner, C., Borken, W., Stange, C. F., and Matzner, E.: Minor response of gross $\mathrm{N}$ turnover and $\mathrm{N}$ leaching to drying, rewetting and irrigation in the topsoil of a Norway spruce forest, Eur. J. Soil Sci., 62, 709-717, doi:10.1111/j.13652389.2011.01388.x, 2011.

Cregger, M. A., McDowell, N. G., Pangle, R. E., Pockman, W. T., and Classen, A. T.: The impact of precipitation change on nitrogen cycling in a semi-arid ecosystem, Funct. Ecol., 28, 15341544, doi:10.1111/1365-2435.12282, 2014.

Davidson, E. A., Nepstad, D. C., Ishida, F. Y., and Brando, P. M.: Effects of an experimental drought and recovery on soil emissions of carbon dioxide, methane, nitrous oxide, and nitric oxide in a moist tropical forest, Glob. Change Biol., 14, 2582-2590, doi:10.1111/j.1365-2486.2008.01694.x, 2008.

Delgado-Baquerizo, M., Maestre, F. T., Escolar, C., Gallardo, A., Ochoa, V., Gozalo, B., Prado-Comesaña, A., and Wardle, D.: Direct and indirect impacts of climate change on microbial and biocrust communities alter the resistance of the $\mathrm{N}$ cycle in a semiarid grassland, J. Ecol., 102, 1592-1605, doi:10.1111/13652745.12303, 2014.

Easterling, D. R., Meehl, G. A., Parmesan, C., Changnon, S A., Karl, T. R., and Mearns, L. O.: Climate extremes: observations, modeling, and impacts, Science, 289, 2068-2074, doi:10.1126/science.289.5487.2068, 2000.

Emmett, B. A., Beier, C., Estiarte, M., Tietema, A., Kristensen, H. L., Williams, D., Penuelas, J., Schmidt, I., and Sowerby, A.: The response of soil processes to climate change: Results from manipulation studies of shrublands across an environmental gradient, Ecosystems, 7, 625-637, doi:10.1007/s10021-004-0220-x, 2004. 
Erguder, T. H., Boon, N., Wittebolle, L., Marzorati, M., and Verstraete, W.: Environmental factors shaping the ecological niches of ammonia-oxidizing archaea, FEMS Microbiol. Rev., 33, 855869, doi:10.1111/j.1574-6976.2009.00179.x, 2009.

Fang, Y., Gundersen, P., Mo, J., and Zhu, W.: Nitrogen leaching in response to increased nitrogen inputs in subtropical monsoon forests in southern China, Forest Ecol. Manag., 257, 332-342, doi:10.1016/j.foreco.2008.09.004, 2009.

Fuchslueger, L., Kastl, E.-M., Bauer, F., Kienzl, S., Hasibeder, R., Ladreiter-Knauss, T., Schmitt, M., Bahn, M., Schloter, M., Richter, A., and Szukics, U.: Effects of drought on nitrogen turnover and abundances of ammonia-oxidizers in mountain grassland, Biogeosciences, 11, 6003-6015, doi:10.5194/bg-116003-2014, 2014.

Gao, J. M., Xie, Y. X., Jin, H. Y., Liu, Y., Bai, X. Y., Ma, D. Y., Zhu, Y. J., Wang, C. Y., and Guo, T. C.: Nitrous Oxide Emission and Denitrifier Abundance in Two Agricultural Soils Amended with Crop Residues and Urea in the North China Plain, PLoS ONE, 11, e0154773, doi:10.1371/journal.pone.0154773, 2016.

Gao, J. G., Zhao, P., Shen, W. J., Rao, X. Q., and Hu, Y. T.: Physiological homeostasis and morphological palsticity of two tree species subjected to precipitation seasonal distribution changes, Perspect. Plant Ecol., 25, 1-19, doi:10.1016/j.ppees.2017.01.002, 2017.

Henderson, S. L., Dandie, C. E., Patten, C. L., Zebarth, B. J., Burton, D. L., Trevors, J. T., and Goyer, C.: Changes in denitrifier abundance, denitrification gene mRNA levels, nitrous oxide emissions, and denitrification in anoxic soil microcosms amended with glucose and plant residues, Appl. Environ. Microbiol., 76, 2155-2164, doi:10.1128/AEM.02993-09, 2010.

Henry, S., Bru, D., Stres, B., Hallet, S., and Philippot, L.: Quantitative detection of the nos $Z$ gene, encoding nitrous oxide reductase, and comparison of the abundances of $16 \mathrm{~S}$ rRNA, narG, nirK, and nos $Z$ genes in soils, Appl. Environ. Microbiol., 72, 5181-5189, doi:10.1128/AEM.00231-06, 2006.

Hu, L.-T. and Bentler, P. M.: Fit Indices in Covariance Structure Modeling: Sensitivity to Underparameterized Model Misspecification, Psychol. Methods, 3, 424-453, 1998.

IPCC (Intergovernmental Panel on Climate Change): Climate change 2007: the physical science basis-summary for policy makers, Contribution of Working Group I to the Fourth Assessment Report of the Intergovernmental Panel on Climate Change, Cambridge University Press, Cambridge, 2007.

Isobe, K., Koba, K., Suwa, Y., Ikutani, J., Fang, Y. T., Yoh, M., Mo, J. M., Otsuka, S., and Senoo, K.: High abundance of ammoniaoxidizing archaea in acidified subtropical forest soils in southern China after long-term N deposition, Fems Microbiol. Ecol., 80, 193-203, doi:10.1111/j.1574-6941.2011.01294.x, 2012.

Jamieson, N., Barraclough, D., Unkovich, M., and Monaghan, R.: Soil $\mathrm{N}$ dynamics in a natural calcareous grassland under a changing climate, Biol. Fert. Soils, 27, 267-273, doi:10.1007/s003740050432, 1998.

Kuzyakov, Y. and Domanski, G.: Carbon input by plants into the soil. Review, J. Plant Nutr. Soil Sc., 163, 421431, doi:10.1002/1522-2624(200008)163:4<421::AidJpln421>3.0.Co;2-R, 2000.

Levy-Booth, D. J., Prescott, C. E., and Grayston, S. J.: Microbial functional genes involved in nitrogen fixation, nitrification and denitrification in forest ecosystems, Soil Biol. Biochem., 75, 1125, doi:10.1016/j.soilbio.2014.03.021, 2014.

Liu, G. S., Jiang, N. H., Zhang, L. D., and Liu, Z. L.: Soil Physical and Chemical Analysis and Description of Soil Profiles, China Standards Press, Beijing, 1996.

Liu, L. L., Wang, X., Lajeunesse, M. J., Miao, G. F., Piao, S. L., Wan, S. Q., Wu, Y. X., Wang, Z. H., Yang, S., Li, P., and Deng, M. F.: A cross-biome synthesis of soil respiration and its determinants under simulated precipitation changes, Glob. Change Biol., 22, 1394-1405, doi:10.1111/gcb.13156, 2016.

Loll, P. and Moldrup, P.: Soil characterization and polluted soil assessment, Aalborg University, Aalborg University Press, Aalborg, Denmark, 2000.

Nautiyal, C. S. and Dion, P. (Eds.): Molecular Mechanisms of Plant and Microbe Coexistence, Soil Biology, Vol. 15, Springer Berlin Heidelberg, doi:10.1007/978-3-540-75575-3, 2008.

Petersen, D. G., Blazewicz, S. J., Firestone, M., Herman, D. J., Turetsky, M., and Waldrop, M.: Abundance of microbial genes associated with nitrogen cycling as indices of biogeochemical process rates across a vegetation gradient in Alaska, Environ. Microbiol., 14, 993-1008, doi:10.1111/j.1462-2920.2011.02679.x, 2012.

Reichmann, L. G., Sala, O. E., and Peters, D. P. C.: Water controls on nitrogen transformations and stocks in an arid ecosystem, Ecosphere, 4, 11, doi:10.1890/Es12-00263.1, 2013.

Schermelleh-Engel, K., Moosbrugger, H., and Müller, H.: Evaluating the Fit of Structural Equation Models: Tests of Significance and Descriptive Goodness-of-Fit Measures, MPR-online, 8, 23 74, 2003.

Schimel, J. P. and Bennett, J.: Nitrogen mineralization: Challenges of a changing paradigm, Ecology, 85, 591-602, doi:10.1890/038002, 2004.

Seager, R., Ting, M., Held, I., Kushnir, Y., Lu, J., Vecchi, G., Huang, H. P., Harnik, N., Leetmaa, A., and Lau, N. C.: Model projections of an imminent transition to a more arid climate in southwestern North America, Science, 316, 1181-1184, 2007.

Shen, J. P., Zhang, L. M., Di, H. J., and He, J. Z.: A review of ammonia-oxidizing bacteria and archaea in Chinese soils, Front. Microbiol., 3, 296, doi:10.3389/Fmicb.2012.00296, 2012.

Stark, J. M. and Firestone, M. K.: Mechanisms for Soil-Moisture Effects on Activity of Nitrifying Bacteria, Appl. Environ. Microbiol., 61, 218-221, 1995.

Tavares, P., Pereira, A. S., Moura, J. J. G., and Moura, I.: Metalloenzymes of the denitrification pathway, J. Inorg. Biochem., 1000, 2087-2100, doi:10.1016/j.jinorgbio.2006.09.003, 2006.

Vance, E. D., Brookes, P. C., and Jenkinson, D. S.: An Extraction Method for Measuring Soil Microbial Biomass-C, Soil Biol. Biochem., 19, 703-707, doi:10.1016/0038-0717(87)900526, 1987.

van der Heijden, M. G. A., Bardgett, R. D., and van Straalen, N. M.: The unseen majority: soil microbes as drivers of plant diversity and productivity in terrestrial ecosystems, Ecol. Lett., 11, 296310, doi:10.1111/j.1461-0248.2007.01139.x, 2008.

Wang, J., Ren, H., Yang, L., and Duan, W. J.: Establishment and early growth of introduced indigenous tree species in typical plantations and shrubland in South China, Forest Ecol. Manage., 258, 1293-1300, doi:10.1016/j.foreco.2009.06.022, 2009.

Widmer, F., Shaffer, B. T., Porteous, L. A., and Seidler, R. J.: Analysis of nifH gene pool complexity in soil and litter at a Douglas fir 
forest site in the Oregon cascade mountain range, Appl. Environ. Microbiol., 65, 374-380, 1999.

Wieder, W. R., Cleveland, C. C., and Townsend, A. R.: Throughfall exclusion and leaf litter addition drive higher rates of soil nitrous oxide emissions from a lowland wet tropical forest, Glob. Change Biol., 17, 3195-3207, doi:10.1111/j.1365-2486.2011.02426.x, 2011.

Wu, Z. T., Dijkstra, P., Koch, G. W., Penuelas, J., and Hungate, B. A.: Responses of terrestrial ecosystems to temperature and precipitation change: a meta-analysis of experimental manipulation, Glob. Change Biol., 17, 927-942, doi:10.1111/j.13652486.2010.02302.x, 2011.

Yi, N., Gao, Y., Zhang, Z., Wang, Y., Liu, X., Zhang, L., and Yan, S.: Response of Spatial Patterns of Denitrifying Bacteria Communities to Water Properties in the Stream Inlets at Dianchi Lake, China, International Journal of Genomics, 2015, 1-11, doi:10.1155/2015/572121, 2015.
Zhalnina, K., de Quadros, P. D., Camargo, F. A., and Triplett, E. W.: Drivers of archaeal ammonia-oxidizing communities in soil, Front. Microbiol., 3, 210, doi:10.3389/fmicb.2012.00210, 2012.

Zhao, Q., Jian, S., Nunan, N., Maestre, F. T., Tedersoo, L., He, J., Wei, H., Tan, X., and Shen, W.: Altered precipitation seasonality impacts the dominant fungal but rare bcterial taxa in subtropical forest soils, Biol. Fert. Soils, 53, 231-245, doi:10.1007/s00374016-1171-z, 2017.

Zhou, G., Liu, S., Li, Z., Zhang, D., Tang, X., Zhou, C., Yan, J., and Mo, J.: Old-growth forests can accumulate carbon in soils, Science, 314, 1417, doi:10.1126/science.1130168, 2006.

Zhou, G. Y., Wei, X. H., Wu, Y. P., Liu, S. G., Huang, Y. H., Yan, J. H., Zhang, D. Q., Zhang, Q. M., Liu, J. X., Meng, Z., Wang, C. L., Chu, G. W., Liu, S. Z., Tang, X. L., and Liu, X. D.: Quantifying the hydrological responses to climate change in an intact forested small watershed in Southern China, Glob. Change Biol., 17, 3736-3746, doi:10.1111/j.1365-2486.2011.02499.x, 2011. 